
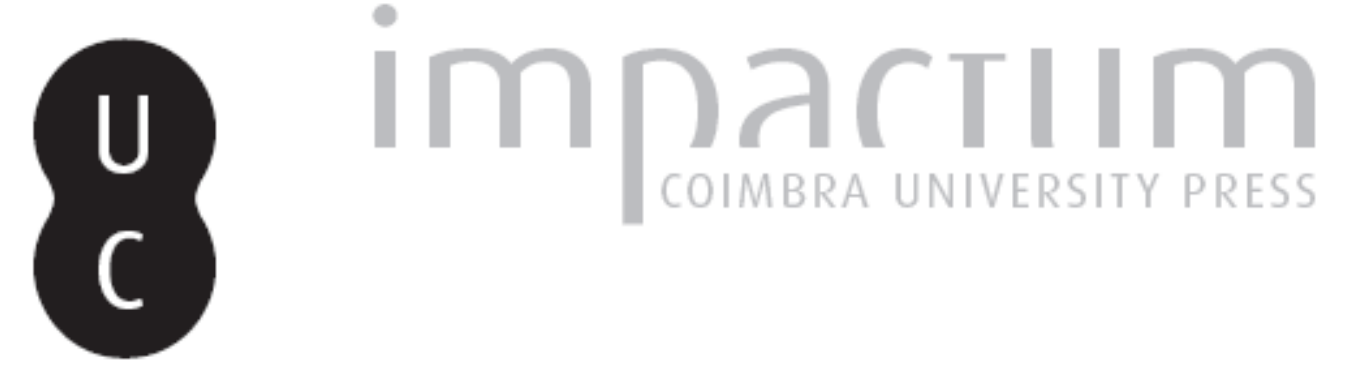

\title{
Interrupted dialogue: recent readings of the symposium
}

Autor(es): $\quad$ Gonzalez, Francisco J.

Publicado por: Imprensa da Universidade de Coimbra

URL persistente:

URI:http://hdl.handle.net/10316.2/42211

DOI: DOI:https://doi.org/10.14195/2183-4105_8_5

Accessed : $\quad$ 26-Apr-2023 06:59:50

A navegação consulta e descarregamento dos títulos inseridos nas Bibliotecas Digitais UC Digitalis, UC Pombalina e UC Impactum, pressupõem a aceitação plena e sem reservas dos Termos e Condições de Uso destas Bibliotecas Digitais, disponíveis em https://digitalis.uc.pt/pt-pt/termos.

Conforme exposto nos referidos Termos e Condições de Uso, o descarregamento de títulos de acesso restrito requer uma licença válida de autorização devendo o utilizador aceder ao(s) documento(s) a partir de um endereço de IP da instituição detentora da supramencionada licença.

Ao utilizador é apenas permitido o descarregamento para uso pessoal, pelo que o emprego do(s) título(s) descarregado(s) para outro fim, designadamente comercial, carece de autorização do respetivo autor ou editor da obra.

Na medida em que todas as obras da UC Digitalis se encontram protegidas pelo Código do Direito de Autor e Direitos Conexos e demais legislação aplicável, toda a cópia, parcial ou total, deste documento, nos casos em que é legalmente admitida, deverá conter ou fazer-se acompanhar por este aviso. 


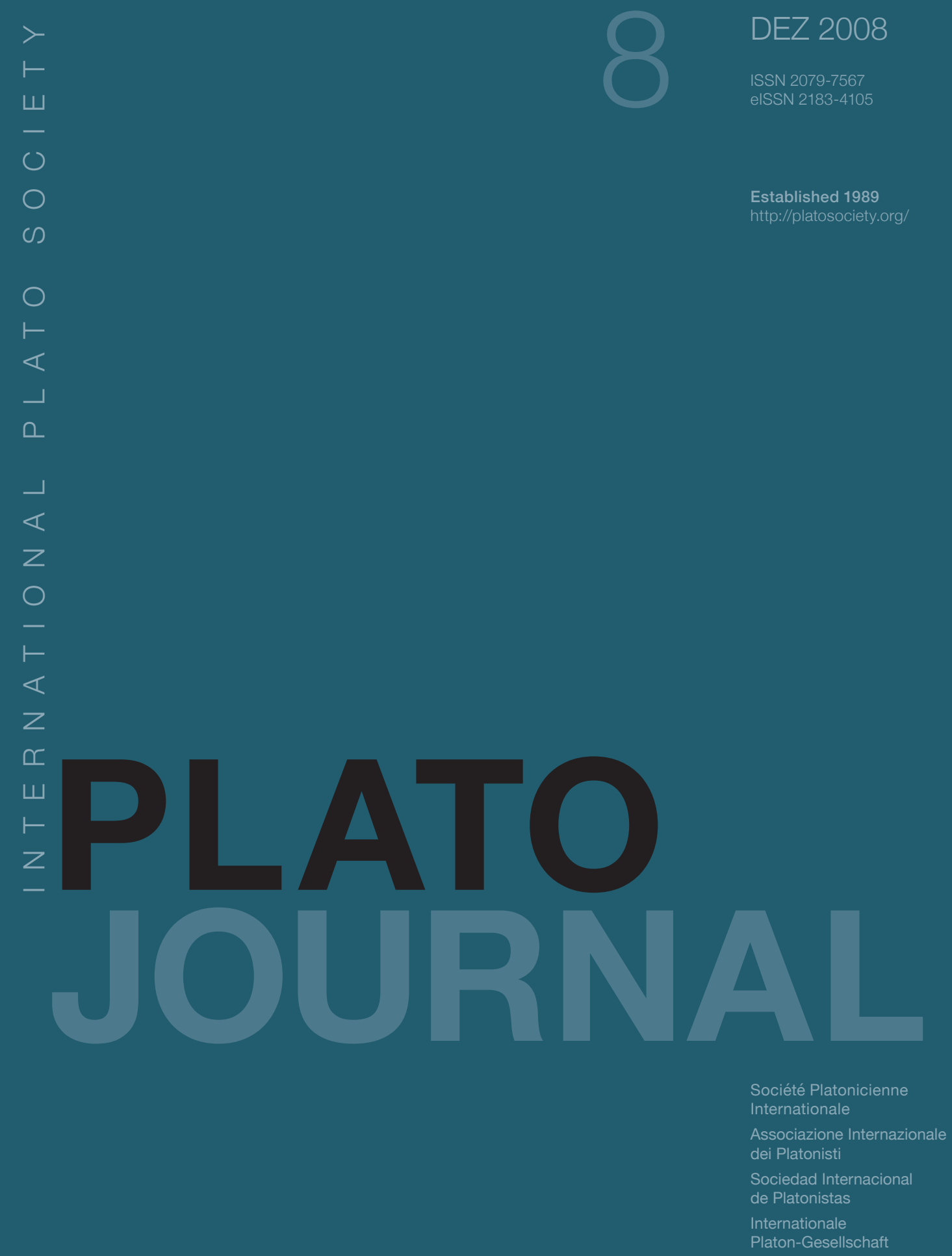




\section{INTERRUPTED DIALOGUE: RECENT READINGS OF THE SYMPOSIUM}

While Plato's Symposium is one of his most admired and widely read dialogues, with its popularity and influence extending well beyond the discipline of philosophy, it is not much of an exaggeration to say that philosophers have not known what exactly to make of it. The three recent books considered here ${ }^{1}$ can be said to take this strange state-of-affairs as their starting point. Thus, for example, Sheffield feels the need to assert at the start of her study that "the Symposium deserves to be taken more seriously by those interested in Plato's philosophy" (3). One thing that motivates the study of Corrigan and Glazov-Corrigan (hereafter C.G-C.) is their stated conviction that no part of the dialogue is "simply nonphilosophical" (42). In likewise alluding to the difficulties the dialogue has posed for philosophical readers, the volume edited by Lesher, Nails, and Sheffield succinctly states the reason: "The Symposium is a curiously constructed work, which has divided scholars who wish their philosophy and literature to be served up separately" (2). The problem is indeed that those turning to the dialogue for 'Plato's philosophy' tend to find it only in Socrates' speech; what then to make of the rest, and by far the major part of the dialogue? What philosophical purpose, if any, is served by the other speeches and by all those literary details and flourishes

${ }^{1}$ Plato's Symposium: Issues in Interpretation and Reception, eds. James Lesher, Debra Nails, and Frisbee Sheffield (Washington D.C.: Center for Hellenic Studies, 2006); Frisbee C. C. Sheffield, Plato's Symposium: The Ethics of Desire (Oxford University Press, 2006); Kevin Corrigan and Elena Glazov-Corrigan, Plato's Dialectic at Play: Structure, Argument and Myth in Plato's Symposium. (Penn State Press, 2004).

PLATO, The electronic Journal of the International Plato Society, n 8, 2008. http://gramata.univ-paris1.fr/Plato

(c) All rights of reproduction of any form reserved. 
that so appeal to readers not so worried about the philosophical content? And even if he or she ignores everything but Socrates' speech, the reader in search of Plato's arguments and doctrines will still find much in this speech to be puzzled by since it is itself a dialogue that reflects in microcosm the literary and dramatic complexity of the dialogue as a whole. Even if one tries to make one's hermeneutical task easier by treating the character Socrates as Plato's mouthpiece, one is still faced with the problem that this character is made to present his account of love in the voice of another character, i.e., the priestess Diotima. The words of this priestess, furthermore, appear rather light in what we would consider today 'philosophical argument' and rather heavier in fantasy and poetic effusion.

The two book-length studies of the Symposium under review here, as well as some of the contributions in the collection of essays, have as their more or less explicit aim showing how the dialogue as a whole is a work of philosophy, which in turn involves showing how all of its parts and diverse elements are both interdependent and indispensable to its philosophical point. To begin with the collection, I emphasize 'some' because it is a very diverse collection (that is indeed one of its major strengths) and a few of the essays it contains work directly against the mentioned aim.

The most extreme example is Lloyd Gerson's contribution. Gerson's argument is that the dialogue is best interpreted from the perspective of 'Platonism', by which he means the combination of the following: 1) the rejection of Eleaticism, materialism, relativism, extreme Heracliteanism, hedonism, and the conception of the soul as a harmony (all of which for Gerson are clearly and unqualifiedly rejected in the dialogues, 53); 2) what Aristotle tells us of the Platonist position; 3) what can be inferred from this position, whether or not Plato explicitly saw the implication (53). Gerson attempts to show that Platonism as thus constituted illuminates the Symposium better than anything else. Yet by "the Symposium" Gerson apparently means only the second-half of Diotima's speech since he makes no attempt to show that Platonism illuminates any other part of the dialogue. Gerson's argument is also weakened by a failure to

PLATO, The electronic Journal of the International Plato Society, n 8, 2008. http://gramata.univ-paris1.fr/Plato

(c) All rights of reproduction of any form reserved. 
seriously consider rival interpretations; how can the 'Platonic reading' be shown to be best without such consideration? Finally, and most importantly, one must be highly suspicious of a hermeneutics that, instead of first interpreting what is said in a dialogue in its own argumentative and dramatic context, instead interprets it according to some 'doctrine' cobbled together from external and heterogenous sources. Such an approach should be resorted to only if the approach taken by Sheffield and C.G-C. in their studies, as well as by some of the other essays in this collection, can be shown to fail.

Some essays in the collection try to reconstruct and examine the implications of Plato's argument as directly inferred from the Socrates/Diotima speech. Thus Gabriel Richardson Lear sets out to determine why beauty plays such in central role in Plato's ethical theory while it plays little or no role in contemporary ethical theories. Her conclusion is that beauty adds a sense of immortality, stability, and self-sufficiency which Plato considers essential to the virtuous life. Gabriela Roxana Carone argues that, despite initial appearances and what other scholars have claimed, philosophy remains a communal rather than a solipsistic affair in Diotima's description of the ascent (221); even if people are only images of true beauty, this does not make them replaceable and substitutable since each can offer a unique combination of beautiful properties (217). Christopher Rowe addresses the development of Plato's thought in arguing that the Symposium is a Socratic dialogue on account of the presence in it of a Socratic psychology and despite the introduction of Forms. This interpretation is in at least partial contrast to that of Sheffield who devotes an appendix of her book to the question and concludes: "Although the evidence of the 'Socratic' picture is stronger, there is no evidence to rule out tripartition either" (239).

Other essays pursue the opposite path of focusing on the literary dimension and showing what influence this dimension has exerted apart from, and even despite any philosophical content. Thus J. H. Lesher's catalogue of images inspired by the Symposium reaches the general conclusion that the dialogue has inspired such a wealth of afterimages not only on account of its memorable scenes and incidents, but also on account of its lack of a clear and

PLATO, The electronic Journal of the International Plato Society, n 8, 2008.

http://gramata.univ-paris1.fr/Plato

(c) All rights of reproduction of any form reserved. 
dominant message: a lack which allows it to be treated by readers as a kind of smorgasbord (338-339). Examining the dialogue's influence on ancient fiction, Richard Hunter shows the highly complicated, indirect and subtle ways in which the works of Apuleius and Petronius in particular appropriate and parody the figure of Socrates and certain of the dialogue's motifs. Diskin Clay's account of the appropriation of the dialogue by Renaissance humanists shows both what embarrassed them (e.g., pederasty and androgyny) and what they were able to use for their own purposes. A very different response to the dialogue is found by David K. O'Connor in the Romantic poets Shelley and Stevens who, in O'Connor's felicitous phrase, "suffer a Platonic desire that refuses a Platonic satisfaction" (361), and for whom "Better an earthy Socrates than a heavenly Form" (374)

Other essays help us to understand the dramatic and literary context of the dialogue by situating it in a broader historical context. Luc Brisson thus attempts to show that the Symposium offers a critique of traditional paiderastia and its conception of education as the transmission of knowledge from master to pupil in a hierarchical relationship, putting in its place a conception of education as the recovery of knowledge from within the already pregnant lover. Angela Hobbs considers how Plato plays with both traditional female and male imagery (and with imagery that is ambiguously one or the other) as a pedagogical device adapted to the level of the student. Though she is careful not simply to identify Diotima with Plato, the following conclusion appears to allow little difference between the two: "The enjoyment of playing with, transgressing and utilizing concepts of gender is possible precisely because, finally, they are of no lasting importance. The Symposium is not so much a rejection of the female as gaily cavalier in its attitude towards the embodied" (271). How is this true of the other speeches that comprise the dialogue? Debra Nails, in considering the dialogue's tragic dimension, locates the real tragedy off-stage: it is the tragedy of how the ignorance of the Athenians led to the exile or death of many of the characters, including Socrates, on the charge of asebeia. An important part of Nails' argument takes us finally to the question of the relation between the different

PLATO, The electronic Journal of the International Plato Society, n 8, 2008.

http://gramata.univ-paris1.fr/Plato

(c) All rights of reproduction of any form reserved. 
parts of the dialogue and the question of where Plato's philosophy is to be located: in maintaining that there is no incompatibility between the love of wisdom and the love of persons, Nails denies that Diotima speaks for Socrates or that Socrates embraces as his own her 'mystical initiation talk' (192-3).

Some of the essays in the collection focus on, and give weight to, speeches other than Diotima's. Rightly emphasizing the pivotal role granted Eryximachus in the structure of the Symposium, Mark McPherran remedies the usual neglect of Eryximachus' speech by showing how his conception of piety and medicine is appropriated and transformed by Diotima in her speech: an interpretation that arguably still makes Eryximachus' speech completely subordinate and reducible to what is said in Socrates's speech. Focusing on Alcibiades' speech, C. D. C. Reeve argues that Alcibiades' mistake is in thinking that the agalmata he sees within Socrates are pieces of wisdom that could be given to him rather than seeing that they are only images that point beyond themselves and thus are meant to inspire a love for philosophical inquiry. Alcibiades fails to see, in short, that Socrates' love can be won only by joining him in living the philosophically examined life (141). While this interpretation of Alcibiades certainly has merit, this reading of his speech as simply a false perspective also appears to make the speech completely subordinate to Socrates' own.

One thus sees that most of the essays in the collection do not find, or even make no attempt to find, philosophical content or truth outside of Socrates' speech and that even those that do make this attempt ultimately find the same content or truth fully incorporated into Socrates' speech. To see something else that characterizes most of the essays, it is worth turning here to one essay that has not yet been considered, both because it deals with the unusual and unique topic of the influence the Symposium has had on legal decisions and because it makes a point about hermeneutics that provides a good point of departure for reflecting on the collection as a whole. Perhaps the most interesting contribution of Jeffrey Carnes' essay is his description of how a certain kind of hermeneutics, which he identifies with the Symposium, has come to work its way into the most recent court decisions. "The kind of reading now favored by literary critics in which

PLATO, The electronic Journal of the International Plato Society, n 8, 2008.

http://gramata.univ-paris1.fr/Plato

(c) All rights of reproduction of any form reserved. 
openness, lack of closure, and dialogue are valued above certainty and structure (what might be termed the Symposium approach), has come to prominence in legal discourse as well" (289). What is striking, however, is that hardly any of the essays in this collection take this so-called "Symposium approach" to the dialogue, as the above survey should make clear. One partial exception is Debra Nails' essay, to the extent that, in rejecting an identification of Plato with Diotima, she opens the way towards a more holistic, open-ended, and dialogical reading of the dialogue.

The only other, and the most noteworthy, exception is the essay by Ruby Blondell. Blondell asks the very important question, though one oddly neglected or answered only in passing in most of the scholarship, of where Socrates is to be located on Diotima's ladder of love. She presents with great detail and insight the cases that can be made for locating Socrates at different steps in the ascent and in the end concludes that Socrates cannot be located at only one step but seems to be present at all of them at once. This means that the very existence of Socrates brings into question the step-by-step, systematic ascent that Diotima describes. This, Blondell suggests, is precisely the atopia to which the dialogue repeatedly draws our attention. Though Blondell does not herself do so, it is tempting to apply her reading to the dialogue as a whole, i.e., to see the atopia of Socrates as also bringing into the question the appearance, at least in the eyes of many scholars, that the series of speeches itself constitutes a systematic ascent. If Socrates cannot be located at any one step of the ascent, might we not likewise argue that Plato cannot be located in any one of the speeches that together constitute the Symposium? Cannot Plato, both in this dialogue and in others, be described, with even more justice than Socrates, as the "Nowhere Man" (Blondell's phrase)? However one answers these questions, what is clear is that Blondell is employing what Carnes calls "the Symposium approach" in a way that the other essays in the collection do not. And even Blondell fails to employ such an approach consistently: in, for example, neglecting the role played by the different perspectives of the different characters through which we see Socrates, i.e., Aristodemus, Apollodorus, and Alcibiades. Blondell sometimes speaks as if it

PLATO, The electronic Journal of the International Plato Society, n 8, 2008.

http://gramata.univ-paris1.fr/Plato

(c) All rights of reproduction of any form reserved. 
were simply Plato who is characterizing Socrates in different and even contradictory ways (161).

What distinguishes the studies by Sheffield and C.G-C. from other studies, as well as from most of the essays in the collection, as well as being the one thing they have in common with one another, is their emphasis on the indispensable and philosophical role played by the speeches other than Socrates'. (Sheffield has an essay in the collection, but I do not discuss it above since its main argument is essentially the same as that of the book). The stated goal of C.G-C. is to read the dialogue "as a whole, each part contributing something vital to the structure of the whole, in a pattern that goes beyond the speech of Socrates alone" (2). Taking this approach they conclude, in the context of interpreting Socrates' speech, that "Platonic love' is represented by the whole of the Symposium up to this point. .." (160; also 234-5). Sheffield likewise seeks to demonstrate that "the speeches have an important philosophical role in the dialogue" (16) and that "The philosophy of the Symposium is extended throughout the dialogue...” (208).

Yet what makes a comparison of these two studies particularly illuminating is that, despite this similar starting-point and goal, they could not be more different in their approach and in the interpretation this approach yields. Just a quick perusal of their pages already exhibits one striking difference. While insisting that "It is difficult to dismiss the previous accounts as nothing more than literary frivolities from this perspective, since they occupy a large part of this text (twenty-seven Stephanus pages compared with nineteen for Socrates)" (31), Sheffield nevertheless devotes only pp. 15-27 to an analysis of these previous accounts (with general discussion of their role on pp. 27-39), while devoting pp. 40-182 exclusively to Socrates' speech. In contrast C.G-C. devote pp. 50-103 to the speeches preceding Socrates', after devoting the first fifty pages to the 'prologues', while devoting pp. 104-162 to the Socrates/Diotima speech: a distribution clearly much closer than Sheffield's to that suggested by the text itself.

PLATO, The electronic Journal of the International Plato Society, n 8, 2008.

http://gramata.univ-paris1.fr/Plato

(c) All rights of reproduction of any form reserved. 
The reason for this difference is not hard to find. If Sheffield sees important questions or problems being raised in the earlier speeches, she appears to find them all resolved and answered in Socrates' speech. If she also finds important truths in the earlier accounts, she clearly believes that these truths are in the end fully incorporated into Socrates' account. Thus towards the end of the book Sheffield can characterize the earlier speeches as a "propaedeutic" to Socrates' speech (219). Given such an approach, there is no need to spend much time on the earlier speeches, but only enough to pick out the anticipations of Socrates' speech. C.G-C., in contrast, criticize precisely readings that attempt to characterize the speeches as following an ascending order of importance culminating with Socrates/Diotima (46-50). While they grant that certain points in the earlier speeches are taken up and corrected in the Socrates/Diotima speech and even locate the positions of the earlier speeches on the ladder of love (though not, as will be seen, in an unambiguous and direct mapping), they nevertheless insist that "the Socrates-Diotima dialectic is not a procrustean reduction of heterodoxy into monochromatic hierarchical Platonic orthodoxy, but the free play of the reflection of others' voices, of ideas, in dialectical transformation; and this is also a recognition that the others' voices are not closed compartments of hermetic meaning" (193). From the perspective of such an approach, the earlier speeches demand careful and detailed analysis in their own right.

The general difference here, as the following detailed consideration of both books will make only clearer, is that while Sheffield finds in the dialogue a gradual and systematic march towards one goal and on one continuous road, C.G-C. find instead an irreducible diversity of paths, a plurivocity, and accordingly emphasize ruptures and discontinuities. The difference is perhaps most explicit in the assertion of C.G-C. that "To be in search of the question of the other is therefore a leitmotif fundamental to understanding the dialogue as a whole" (189), where they identify the 'other' with "not only the many voices and characters, but the different genres which help to frame the work" (189). In short, they, in contrast to Sheffield, take what Jeffrey Carnes has been seen to characterize as "the Symposium approach" to the Symposium.

PLATO, The electronic Journal of the International Plato Society, n 8, 2008.

http://gramata.univ-paris1.fr/Plato

(c) All rights of reproduction of any form reserved. 
In what follows I want to identify what I consider to be some of the weaknesses of Sheffield's reading, in addition to its strengths, and then consider how the C.G-C. approach might remedy some of these weaknesses while suffering from some of its own. The hope is that the contrast between these two radically different approaches to the dialogue will shed some light on the peculiar and evasive character of the dialogue itself.

While Sheffield's analysis of the argument of Socrates' speech is so rich and detailed that it is hardly possible to do justice to it here, what this analysis ultimately takes the argument to be about is how eros, which always involves certain beliefs about what is good and valuable, can be educated through philosophical reasoning (see, e.g., 55), where this education culminates in a conception of the best life as the life of contemplation (79). While such a highly 'rationalistic' reading of the speech is consistent with Sheffield's approach to the dialogue as a whole, it is nevertheless, I wish to show, in tension with various crucial elements in the speech.

Commenting on 203e3-4, Sheffield asserts: "It is important to notice that it is neither said nor implied that the resulting provision is knowledge nor, consequently, that Eros' fluctuation takes place from knowledge to ignorance. This would suggest that if knowledge were supplied then that, too, would 'flow away', but Eros' fluctuation is one that operates between knowledge and ignorance" (63). The only thing that fluctuates or flows away is, according to Sheffield, a logos that is unstable because not supported by the right logos (65). Yet oddly, despite the great detail of her analysis, Sheffield avoids direct discussion of the passage (207e5-208a7) in which Diotima explicitly maintains that each piece of knowledge we have (episteme) suffers the fate of constantly flowing away and therefore constantly needing to be replaced by something similar. This oversight is odd but perhaps also telling. What is so striking in what Diotima says is the suggestion that even knowledge is not immune to the instability of our erotic natures; but this is a suggestion incompatible with a conception of eros as a steady march towards the possession of knowledge and its enjoyment in contemplation.

PLATO, The electronic Journal of the International Plato Society, n 8, 2008. http://gramata.univ-paris1.fr/Plato

(c) All rights of reproduction of any form reserved. 
One of the central, and in my view oddest, interpretative claims in Sheffield's account is that "Socrates divides the productive activities of different desiring agents into the lower and higher mysteries of eros" (110). This is odd because there is no indication in the text that the distinction between lower and higher mysteries is one between different desiring agents. The only distinction Diotima makes between different desiring agents, i.e., between those pregnant in body and those pregnant in soul, belongs as a whole to the lower mysteries. Since the person pregnant in soul is already described as being drawn to a beautiful soul or a beautiful body or both (while Sheffield characterizes those who are pregnant in soul as turning "towards the beauty of soul (or combination of bodily and psychic beauty, $209 \mathrm{~b} 6$ with 210b6-7)" [94], the text [209b4-5] clearly allows that they could also turn only to bodily beauty), there is no reason not to think that this is the same agent who can begin the ascent up the ladder of love in the higher mysteries. Yet Sheffield assumes throughout the following analysis a sharp distinction between DLM (Desiring Agent of the Lower Mysteries) and DHM (Desiring Agent of the Higher Mysteries). When at the end of her analysis Sheffield shows ways in which "The description of the DHM cleverly mirrors the DLM" (138-139), one must retort: "Of course, since they are not different agents to begin with!" Even if the so-called DLM is motivated by honor (and it is far from clear that the lover's emulation of Homer on account of the immortal fame his 'children' have procured the poet [209d1-4] makes honor his exclusive motive), there is no reason why that motive could not provide an initial impetus up the ascent.

There is, however, a reason why Sheffield needs this sharp distinction between DLM and DHM. Because she sees the ascent up the ladder of love in the Higher Mysteries as "methodical" (138; a 'methodological procedure', 118), deliberate, and the product of rational argumentation, she is required to characterize the agent who makes this ascent as being a philosopher from the very outset (119). But this description of the ascent seems fundamentally wrong. On Sheffield's account, for example, the lover deliberately tries to see the unity between different cases of beauty, e.g., different beautiful bodies, and therefore is reflecting

PLATO, The electronic Journal of the International Plato Society, n 8, 2008. http://gramata.univ-paris1.fr/Plato

(c) All rights of reproduction of any form reserved. 
upon the nature of beauty already on the very first rung of the ladder. It is thus a deliberate 'intellectual engagement' (119) with beauty that moves the agent up the ladder. But there is simply no indication of this in the text; all we are told there is that the lover, after loving one beautiful body, comes to see (katanoêsai) that the beauty in this body is akin to the beauty in another body (210a7-b1). Sheffield at one point asserts that "the DHM only realizes the inferiority of lesser beautiful objects after he has arrived at a more elevated state of awareness: that sense of the lower state, then, cannot be what enables him to reach the higher" (125). But the interpretation Sheffield favors is here asserted with no evidence whereas the interpretation she dismisses, equally without argument, seems the more plausible: it is a sense of the inadequacy and insufficiency of the lower manifestations of beauty that propels the agent up to higher manifestations: a process well described in the Phaedo with the example of how we recollect equality in perceiving equal sticks to fall short of it (74b-75b) and in the Republic with the example of how contradictory perceptions turn our minds towards the Forms $(523 \mathrm{e}-524 \mathrm{e})$. As for how one can recognize the inadequacy of a certain manifestation of beauty before having a clear grasp of the nature of beauty, Sheffield herself provides the answer in suggesting that "There is something about the soul itself which directs its growth, development, and characteristic activity towards this specific end" (129-130). She later describes this as "a noetic disposition in the soul to grasp the form" (132) and compares this idea with the theory of recollection in other dialogues (132).

As for the top of the ascent, or the end of all erotic aspiration, Sheffield characterizes it as nothing but contemplation of the Form (135). But such an interpretation apparently requires him to identify the virtue that is produced by the vision of Beauty Itself with only "the virtue of nous" (134). She must also assume that this goal does not require other persons: "We have no need to import another soul, or souls, in which the DHM produces, nor need we suppose that there are further productive acts required to secure his eudaimonia" (149). Thus in responding to Vlastos' critique of Platonic love, Sheffield in essence grants that

PLATO, The electronic Journal of the International Plato Society, n 8, 2008.

http://gramata.univ-paris1.fr/Plato

(c) All rights of reproduction of any form reserved. 
Vlastos is right, but tries to turn his objection into a virtue: Platonic eros indeed does not refer centrally to love for individuals since no person or persons could satisfy our aspiration for good things and happiness; one would have to be "the most committed romantic" to think otherwise (161; see also 162 and 181). But Sheffield does allow that concern with individuals can play a role in earlier stages of the ascent (171) and that concern for others is not incompatible with loving the Form (174): after all, their beautiful bodies and souls embody what is valuable in the Form and therefore can be intrinsically valuable for that reason (173). Sheffield also allows that there is a 'downward journey' from the contemplation of the Form, a journey portrayed dramatically in the relation between Socrates and Diotima (179). But this downward journey is at least in part a result simply of the fact that "human beings cannot engage in continuous contemplative activity" (179). It is also unclear to Sheffield whether helping others make the ascent is part of the proper nature of eros or just a result of it (178-179); it perhaps is just due to our "demonic nature" as intermediaries between gods and mortals (177). In conclusion, "Contemplation of the form may not require another person, but our natures may require us to keep realizing that activity in our lives and to communicate back from the divine form to the realm of human concern" (182). Whether Diotima's account really assigns to persons such a marginal role in eros is debatable; one should contrast on this point the article by Carone referred to above. But even if Sheffield's reading of Diotima's account is correct, the question remains of whether this account represents all there is to 'Platonic love' or is not rather supplemented in important ways by the other speeches, Alcibiades' in particular.

Other scholars have indeed seen Alcibiades's speech as pointing to some serious limitations in the account of Socrates/Diotima, but, unsurprisingly, Sheffield does not see it that way. She is, on the contrary, at pains to show how Alcibiades's description of Socrates simply mirrors the portrayal of eros in Socrates' speech (186-188). It is in this context that Sheffield suggests that Socrates has not completed the ascent (196); his wisdom consists only in knowing "the practices outlined in the ascent" (p. 196, n. 27; see also p. 200 on

PLATO, The electronic Journal of the International Plato Society, n 8, 2008. http://gramata.univ-paris1.fr/Plato

(c) All rights of reproduction of any form reserved. 
how he who knows eros thereby combines comedy and tragedy). In a chapter significantly entitled "Defending Socrates as Educator", Sheffield puts all of the blame on Alcibiades: like Aristodemus and Apollodorus, he was too fixated on Socrates to recognize the real object of the mysteries of eros (204). The function of Alcibiades' speech is therefore only to serve as a response to the objection (which, according to Sheffield, Aristophanes had tried to make: 137) that philosophical eros on Socrates' account is hubristic and unconcerned with human affairs (212; see also 195). In this way Alcibiades' speech too is fully subordinated and assimilated to that of Socrates.

How different the approach of C.G-C. is can perhaps best be seen if we begin with that aspect of their interpretation in which it is most like Sheffield's. Speaking of the ladder of love, C.G-C. attempt to show that "The apparent abstractness of this ascent is mitigated by the fact that the ascent refashions and transforms the positions of earlier speakers, though this has escaped attention entirely and so only its subliminal force is felt" (150). Thus it might seem that they, like Sheffield, see the earlier speeches as simply anticipating Socrates' speech and therefore being fully taken up and superseded by it. Yet the words 'refashions' and 'transforms' in the cited passage already indicate an important difference, since what C.G.-C. will proceed to show is far from a simple and clear mapping of the speeches onto the different rungs of the ladder. They instead are also at pains to show the ways in which the speeches resist such a simple classification.

While, to begin with, they place Phaedrus's speech on the first rung due to its focus on loving one person (151), they also insist that this speech is closest to Socrates' in its devotion to the subject matter, so that "each point of Phaedrus' speech, unlike those of later speeches, will receive a thorough treatment from Socrates" (54; see correspondences listed on pp. 54-56). As for the second rung, or loving all beautiful bodies, they find no correspondence to any of the reported speeches and must therefore assign it to the speeches that immediately succeeded Phaedrus' but were forgotten by Aristodemus (151). Pausanias' speech is made to correspond directly to the rung of loving a beautiful soul (152), but the detailed analysis of this speech, in drawing attention to the contradiction between its

PLATO, The electronic Journal of the International Plato Society, n 8, 2008.

http://gramata.univ-paris1.fr/Plato

(c) All rights of reproduction of any form reserved. 
contempt for the body and its insistence on the beloved satisfying the lover, shows it to be only the semblance or deconstruction of this rung: in other words, "a chilling example of what could be absolute immorality disguised as the highest virtue..." (61). Eryximachus' speech is shown to correspond to the rung of loving science (153), but he is also shown to betray this rung in subordinating all other sciences to medicine and in allowing his need for order to eliminate the passion, as well as the clash of opposites (see 67), necessary for science (153). While there at first glance appears to be no correspondence between Aristophanes' speech and the next rung, the authors insist that Aristophanes' mathêma of human nature is an image, albeit a distorting one, of the mathêma of the beautiful (154-155). They likewise suggest that Aristophanes' description of the human quest for unity provides "a bastardized form" of the synoptikos dialectic of the Republic (156; see also 80-81). The purpose is to show that, while Aristophanes' speech may illustrate the defective mimetic art criticized in the Republic (76-78), it is nevertheless the case that "for Plato in the Symposium, philosophy has more in common with desirous art than it does with blinkered, comprehensive science" (85). Finally, as for Agathon, he represents "the last step on the ascent of love, but in his own flawed way, for he will never see true beauty face-to-face until he learns the nature of needy desire or faces the necessity of going outside himself and recognizing that his nature is not whole or self-sufficient. Without need, he will see only his own image" (157). Thus, while C.G-C. try to establish correspondences, they also show to what extent these correspondences are distortions and semblances, as well as the extent to which the significance of the speeches is not exhausted by such correspondences. The meaning of each speech is not fixed nor is therefore the nature and extent of their interrelations. One of the key principles that guide the interpretation of C.G-C. is clearly what they themselves describe as "the infinite plasticity" of reality (191-192).

If C.G-C. insist that the relation of Socrates' speech to its predecessors is fluid and ambiguous, they also insist that it is open-ended in its conclusions. They make this point with special clarity in the following passage: "But while Socrates'

PLATO, The electronic Journal of the International Plato Society, n 8, 2008.

http://gramata.univ-paris1.fr/Plato

(c) All rights of reproduction of any form reserved. 
speech is magnificent, and while it 'recollects' both itself and all the previous speeches in a complex structure of address, contrast, destruction, dialogue, and yet also ascent, the speech is still not self-sufficient, for it raises far more questions than it has answered: the questions of immortality, the soul-body relation, human identity, and the relation of art and philosophy, to mention only a few" (162). To these unanswered questions one can add the question of the relation between the love Diotima describes and the love of persons. Arguing against Vlastos (see especially 136-137) that Socrates' speech does not focus on one type of love but instead examines love in its widest application, they add that Socrates' speech does not stand alone but is supplemented by other speeches in which the individual is made central: "Plato gives us two compelling portraits of what it means to love an individual for the individual's sake, first, in Aristophanes' speech and, then, even more powerfully and concretely, in Alcibiades' eulogy" (107).

As for Alcibiades' speech, C.G-C., like Sheffield, and unlike Blondell in the paper discussed above, point to the central failing of Alcibiades, one he shares with Apollodorus and Aristodemus: all three, they observe, "are powerful examples of the love of the individual for the individual's sake that powerfully miss the mark, and with fatal consequences in Alcibiades' case" (179). Yet they also assign a number of positive functions to Alcibiades' speech (see 166). Worth special notice is how Alcibiades shows, on their account, the difficulty of pinning Socrates down: his portrait makes Socrates utterly unique, constantly in motion (even when he is standing still but still searching, 173), and atopos. C.G-C. cite here Alcibiades' avowed inability (214e9-215a3) to count the qualities of Socrates' atopos character in a way that is euporôs and ephexês (170). In thus pointing to the tension between Socrates' character and the orderly and successful ascent of love described by Diotima, their reading complements that of Ruby Blondell.

This suggestion of a tension between Socrates and Diotima is another important feature of the C.G-C. interpretation. While they apparently would not go as far as Debra Nails in simply denying that Diotima speaks for Socrates (1923 ), they do assign her character the central function of introducing the other, and

PLATO, The electronic Journal of the International Plato Society, n 8, 2008.

http://gramata.univ-paris1.fr/Plato

(c) All rights of reproduction of any form reserved. 
thus the possibility and indispensability of dialogue, into the heart of Socrates' account. As they clearly state the point: “... Diotima represents the living reality of dialogue itself, whether she is fictional or not, namely, that the other dialectical pole be really other, and not one's own voice or wishes masked as otherness, so that one can be genuinely changed by the experience of encounter and come to give birth to a reality that is not digestible, but that can be tested." (118). It should be noted that Sheffield too implies a distinction between Diotima and Socrates to the extent that "Diotima embodies the euporetic aspect of erôs which transcends the limitations of a mortal, deficient, nature" (67) whereas Socrates "embodies both the aporetic and euporetic aspects of erôs" (p. 196, n. 27). Yet Sheffield nevertheless appears to assume a perfect coincidence of their perspectives in the ascent, whereas C.G-C. appear to want to emphasize some irreducible otherness here.

Indeed, as already noted in general and confirmed in the interpretative details mentioned here, what most characterizes the C.G-C. interpretation is their emphasis on difference or otherness: i.e., on the disparateness of the different elements, perspectives, speeches in the dialogues and their resistance to full incorporation into one comprehensive perspective and narrative. The C.G-C. interpretation is therefore especially sensitive to the many strange discontinuities and disruptions that so characterize this dialogue that they cannot plausibly be said to be unintended by Plato; indeed, their interpretation considers such 'disorder' a central theme of the dialogue. One of the most obvious dramatic examples is Aristophanes' hiccupping which disrupts the order of the speeches (63); but this 'order' has already been threatened by the many forgotten speeches and the impossibility of clearly visualizing the seating arrangement (27). The other obvious dramatic example is the entrance of Alcibiades; here the disruption is even named with the word exaiphnês: Alcibiades' arrival is perceived 'all of a sudden'. Furthermore, this same word is used to signal other sudden turns that introduce discontinuity into the orderly progression of the narrative: the sudden appearance of Beauty Itself, the sudden appearance of Socrates besides Agathon when Alcibiades is in the process of crowning the latter, the sudden crashing of

PLATO, The electronic Journal of the International Plato Society, n 8, 2008.

http://gramata.univ-paris1.fr/Plato

(c) All rights of reproduction of any form reserved. 
the party by revelers that brings to an end Eryximachus' plan for an orderly and sober symposium. Commenting on these examples, C.G-C. write: "So, like the highest beauty, Alcibiades, Socrates, and the last group of revelers burst onto the scene with the force of a revelation that cannot be compelled or managed" (164). Presumably for C.G-C. the revelation that cannot be compelled or managed is ultimately what the dialogue as a whole reveals about the nature of love.

But does not such a reading ultimately reduce the dialogue to incoherent and directionless play? One great merit of the C.G-C. study is how they show that the 'play' which characterizes the dialogue on their reading, far from lacking seriousness or being philosophically unproductive, instead is an instantiation, a putting into practice, of Plato's dialectic. If the Symposium appears fragmented into such disparate elements, this is because only the dialectical contrast, juxtaposition, and opposition of such elements can generate insight into what is ultimately inexpressible. C.G-C. take as their model here the account of dialectic in the Seventh Letter (194ff.), according to which it is the elenctic 'rubbing together' of words, images, propositions, and true beliefs that sparks insight into the true being of something. Thus they suggest that "All the voices, persons, and genres in the Symposium are not unlike the four 'elements' in the Seventh Letter rubbed together in a dialogue that calls them fundamentally into question ..." (195; see also 208) and that what is sought as other is ultimately "the silent Good" (196). Therefore, if their interpretation emphasizes irreducible diversity and unsystematic play, that is because both this diversity and play are essential to dialectic; if they emphasize the constant incursion of 'the other' into the narrative and argument of the dialogue, this is because what this dialectic aims at is something inescapably other that cannot be fully assimilated to any one speech or perspective: i.e., the Good. By emphasizing the transcendence of the Good they are also able to take as their model the account of dialectic in the Republic (204206; see also 213-214). The dialectical play here, if characterized by the 'absence of foundation' and thus opposed to any sort of system-building, is still capable of transcending, if only partially and fleetingly, "the fractured limits of language" in a nonpropositional understanding of 'the silent Good' (206).

PLATO, The electronic Journal of the International Plato Society, n 8, 2008. http://gramata.univ-paris1.fr/Plato

(c) All rights of reproduction of any form reserved. 
If I have emphasized here what the Sheffield approach misses and what the C.G-C. approach adds, this is not to suggest that the latter is not without its problems. While Sheffield's interpretation provides a clear, consistent, and welldefended conception of love, the C.G-C. interpretation must leave the reader in the end extremely puzzled about just what love is supposed to be according to Plato. More specifically, the kind of meticulous and illuminating analysis of the argument one finds in Sheffield is largely absent in the C.G-C. book, being too often replaced with inflated rhetoric: e.g., Pausanias' argument is dismissed as 'flawed' (60) with little explanation of what exactly the 'flaw' is; Aristophanes' speech is characterized as "a gigantic contradiction" (74) on no more grounds, apparently, than that his images raise problems and questions; the talk of 'the beautiful itself in the Socrates/Diotima speech is referred to as that "apparently airy-fairy business" $(105,108)$ with no explanation or justification. Furthermore, one often has the sense in reading the C.G-C. book of losing the forest for the trees. Interpretative detail is piled onto interpretative detail for page after page with no clear outcome or hermeneutical 'pay-off. To their credit, C.G-C. are themselves aware of this danger: "How are we supposed to read a Platonic dialogue if every incidental detail is potentially significant? And where do we draw the line between legitimate interpretation and pure fancy?” (21). But after many pages devoted to the possible significance of many details in the dialogue's prologues, they appear to find no way of drawing this line given what they describe as the many levels of signification in Plato's play (42). The result, practically speaking, is a seemingly random assortment of suggestions and hints that do not add up to any overall interpretation and that therefore leave the reader more confused than enlightened.

These three books on the Symposium reflect very well the general state of contemporary Platonic scholarship: a diversity of radically different approaches, each with its own strengths and weaknesses, none fully satisfying. We could of course lament this state of affairs as a state of fragmentation and chaos. We could seek to remedy it by fighting for an approach we decide to be the best and dismissing the others as unworthy of consideration. But we could also adopt the

PLATO, The electronic Journal of the International Plato Society, n 8, 2008. http://gramata.univ-paris1.fr/Plato

(c) All rights of reproduction of any form reserved. 
attitude arguably suggested by the Symposium itself: to celebrate the diversity of perspectives without ever renouncing the avowedly endless quest of unifying them.

Francisco J. Gonzalez

PLATO, The electronic Journal of the International Plato Society, n 8, 2008. http://gramata.univ-paris1.fr/Plato

(c) All rights of reproduction of any form reserved. 